\title{
Research and higher education scenario in select Indian state universities: an analysis
}

\author{
P. K. Shetty, M. B. Hiremath ${ }^{1}$, M. Murugan and K.G. Sreeja \\ School of Natural Sciences and Engineering, National Institute of Advanced Studies, Indian Institute of Science \\ Campus, Bangalore- 560 012, India; ${ }^{1}$ KLES Kidney Foundation, Belgaum- 590010, India \\ murigendra@gmail.com
}

\begin{abstract}
This article presents results of an analysis of higher education and research scenario in ten state universities of India during 2000 to 2006. Calcutta University ranked first in terms of published research articles, on an average 664 articles in a year in peer reviewed national and international journals. Similarly Madras, Panjab, Rajasthan, Mysore, Gauhati, Pune, Mumbai, Patna and Sikkim Manipal Universities published 600, 582, 538, 328.33, 221, 184.33, 112.5, 47 and 5 articles respectively. The ratio of number of faculty to research publication varied from 1:0.05 to 1:1.9 in the selected universities. University of Madras, Panjab, Rajasthan and Calcutta have ratio more than 1:1. University of Madras received the maximum research funds of 41.46 crore rupees and ranked first among the selected ten universities. Considering the overall performance of universities in our analysis, Calcutta University and Madras University captured the first two places respectively.
\end{abstract}

Keywords: Indian university, Scientometrics, research, higher education, technometrics, research funding

\section{Introduction}

Higher education has long been recognised as a major contributing factor to the social, cultural and intellectual life of society by improving the quality of human life. According to the latest statistics available, there are 483 universities in India today (39 Central Universities; 255 State Universities; 59 private universities; 130 deemed universities) (http://education.nic.in/HigherEdu/list-deemeduniv.asp, extracted on $25^{\text {th }}$ April 2010), and over 16,885 colleges including 1,798 colleges for women. In addition to this there are 1173 polytechnic institutes (UGC, 2007). The Government of India has been recommended to increase the educational outlay to 6 per cent of the GDP from the present 3.5 per cent. In most developed countries a significant proportion of the populations (up to $50 \%$ ) now receive higher education at some time in their life period. The current enrolment ratio in India (below $9 \%$ ) is less than the average of lower middle income countries in the world. In terms of scientific information output, Indian contribution is just $1.23 \%$ of world share. However, the number of publications from India has increased considerably from 15,000 papers per year in 2000 to nearly 25,000 papers per year in the last five years (Miyairi, 2006).

As per section 12(B) of the UGC act, State universities established after June 17, 1972, shall not be eligible to receive any grant from the Central Government, the UGC or any other organization receiving funds from the Government of India, unless the Commission satisfies itself, as per the prescribed norms and procedures, that such a university is fit to receive such grants. The UGC has been making budgetary plan allocation for only 112 state universities, excluding medical and agricultural universities. However, the other state universities, technical universities and agricultural universities with engineering and technology departments also obtain benefits from the UGC in the form of special grants. The present work is an attempt to study the state of higher education; in particular the research scenario, in science and technological fields in select state universities in India. Uuniversity research activities were critically examined based on internationally accepted metrics such as the credentials of the faculty, PhDs awarded, research publications, patents secured and recognition accorded via cited publications, major research grants and awards. This study is confined to only ten selected state universities from the different regions of the country. The findings from this study would be useful to understand regional disparities in science and technological developments in the country.

Methodology and data sources

Two state universities from each region viz. East, West, North, South and North-East were selected for this study. The criteria used for selection of these universities were based on the historical and regional importance of the university, National Assessment and Accreditation Council, (NAAC) rating, funding received from various agencies (DST and DBT), successful alumni members of the university, and the present status of higher education in these universities as reported in the available literature. The required information (credentials of the university faculty, Ph.D. awarded, research publications, patents secured and recognition accorded via cited publications, major research grants and awards) for this study was obtained through the Annual Reports (Annual Reports, 2000-2006) of the respective universities, pre-designed protocols and schedules, the official websites of the universities, Google scholar, NAAC Reports and personal interactions with the concerned officials. Data from the
Sci. Technol.Edu.

CIndian Society for Education and Environment (iSee)
"Comparison among Indian universities" http://www.indjst.org
Shetty et al. Indian J.Sci.Technol. 
Table 1: Selected state universities and their research publications/ year and citations

\begin{tabular}{|c|c|c|c|c|c|c|c|}
\hline Region & State Universities & Faculty & $\begin{array}{l}\text { No: of Research } \\
\text { publications / } \\
\text { year }\end{array}$ & $\begin{array}{c}\text { Ph.D. } \\
\text { awarded/ } \\
\text { year }\end{array}$ & $\begin{array}{l}\text { In house } \\
\text { journals }\end{array}$ & $\begin{array}{c}\text { Books } \\
\text { published / } \\
\text { year }\end{array}$ & $\begin{array}{c}\text { GS }^{*} \text { Citations } \\
\text { as of } 23 \text { May } \\
2006\end{array}$ \\
\hline \multirow[t]{2}{*}{ North zone } & \multirow{2}{*}{$\begin{array}{c}\text { University of Rajasthan } \\
\text { Panjab University }\end{array}$} & 345 & 538 & 219 & NA & 50 & 12,400 \\
\hline & & 636 & 582 & 227 & 4 & 25 & 5,610 \\
\hline \multirow[t]{2}{*}{ East zone } & \multirow{2}{*}{$\begin{array}{l}\text { University of Calcutta } \\
\text { Patna University }\end{array}$} & 650 & 664 & 139.6 & 20 & NA & 35,300 \\
\hline & & 345 & 47 & 101.2 & NA & 4 & 3,420 \\
\hline \multirow{2}{*}{$\begin{array}{l}\text { North- east } \\
\text { zone }\end{array}$} & \multirow{2}{*}{$\begin{array}{c}\text { Gauhati University } \\
\text { Sikkim- Manipal University }\end{array}$} & 401 & 221 & 102.5 & NA & NA & 916 \\
\hline & & 102 & $5(\mathrm{GS})^{*}$ & $\mathrm{NA}$ & NA & NA & 58 \\
\hline \multirow[t]{2}{*}{ South zone } & \multirow{2}{*}{$\begin{array}{l}\text { University of Madras } \\
\text { University of Mysore }\end{array}$} & 306 & 600 & 381.2 & 5 & 50 & 34,800 \\
\hline & & 354 & 328.33 & 152.66 & 3 & 86 & 10,400 \\
\hline \multirow[t]{2}{*}{ West zone } & \multirow{2}{*}{$\begin{array}{l}\text { University of Mumbai } \\
\text { University of Pune }\end{array}$} & 587 & 112.5 & 322 & NA & 15 & 20,000 \\
\hline & & 300 & 184.33 & 232.25 & NA & 20 & 13,600 \\
\hline
\end{tabular}

Source: Annual reports of the universities; University official website; Google search; *GS Google scholar; NA- Not available, Validated data received from the universities

annual reports and the pre-designed protocols and schedules were keyed into a software database and then were compiled into comparative tables of the universities which were classified according to regions. Statistical means were derived for the overall percentile scores of all the departments of the university put together, and for those of comparable universities. Further, the percentile scores of criterion-wise data of only comparable universities were calculated to judge the effectiveness of the process of assessing the state of higher education and the research scenario in the Indian universities.

\section{Results and discussion}

\section{Scientometrics}

As per the latest available annual reports of the selected universities in different zones of the country, there is a variation in terms of research output i.e., number of research publications per year. Calcutta University published an average of 664 research articles in peer reviewed national and international journals. Similarly Madras, Panjab, Rajasthan, Mysore, Gauhati, Pune, Mumbai, Patna and Sikkim Manipal Universities had published $600,582,538,328.33,221,184.33,112.5$, 47 and 5 respectively (Table 1 ). The number of publications was more from University of Calcutta as it has the highest number of faculty and 20 in-house journals published from the university. University of Calcutta is the oldest university in the country with 42 chairs of excellence in the university which helped to carry out research and publish more research papers when compared with other selected state universities.

\section{Citation index and citation analysis}

The impact of scientific publications is often estimated by the number of citations they receive, i.e. how frequently they are referenced by other publications. Since publications have associated authors, originating institutions and publication venues (e.g. journals, conference proceedings) citations have also been used to compare their scientific impact. The tremendous scope of new scientific archives like Google Scholar makes it possible to freely access citation data for millions of publications and authors and thus to evaluate the citations for entire conferences and journals (Rahm \& Thor, 2005).

In recent years, research publication in journals cited in Science Citation Index (SCl) and Social Sciences Citation Index, (SSCl) has become a prerequisite for a scientist or a professional seeking placement in reputed universities or research organizations. Indian Council of Medical Research (ICMR) and other councils give importance to research publications in $\mathrm{SCl}$ journals from a research scholar while considering him for selection for the award of a research fellowship. The University Grants Commission (UGC) also focuses on citation index of publications of authors for academic evaluation. The fact that $\mathrm{SCl}$ journals, the impact factor and citation index are used for various research purposes is definitely due to a growing acceptance of assessing the value of a research paper by these parameters. Citations of Indian research have increased constantly since 1980 . Indian research publications have received 221,563 citations in the latest 5 years (1981-2005) and this is nearly four times the number of citations received in early 80's (WOS, 2005).

In the Google scholar citation analysis, Calcutta, Madras and Mumbai universities have highest number of citations as these universities are the oldest with 150 years of existence with more specialised departmental faculty, faculties and facilities. However, Pune and Rajasthan universities which are 58 and 60 years old have 13,600 and 12,400 citations and occupy their position next to Mumbai University, respectively. If we carefully look at the developments in the new universities, it can be noted that these newer universities are working hard to match the older universities in terms of publications, citations etc. which is a very healthy sign. For example, the 150 year old University of Madras with strength of 306 faculty published an average of 600 papers annually. However, the 60 years old University of Rajasthan with 345 faculty published about 538 research publications. Similarly, University of Pune (58 years old) though the number of publications per year was comparatively less (184.33), the number of citations rose
Sci. Technol.Edu.

CIndian Society for Education and Environment (iSee)
"Comparison among Indian universities" http://www.indjst.org
Shetty et al. Indian J.Sci.Technol. 
to 13,600 which showed the enhanced activities of the university. On the other hand, University of Mumbai (150 Years old) had 587 faculty and published about 112.5 publications per year and the university had a citation of only 20,000 . This again proved the point that the newer universities are catching up with the older universities in terms of publications, citations etc. There was regional disparity in terms of performance of the universities. For instance, Patna and Mysore University were almost 90 year old and Patna University had less number of publications as well as citations compared to Mysore University. Panjab University had published 581.5 papers per year but the citation has not been increased considerably. The main reason for this disparity could be publication of large number of papers in Indian journals that are not included in the $\mathrm{SCl}$ or SSCI.
Table 2. The number of faculty to research publication ratio and faculty to Ph.D. awarded per year ratio

\begin{tabular}{|l|l|c|c|}
\hline Region & University & $\begin{array}{c}\text { Faculty: } \\
\text { Publication } \\
\text { ratio }\end{array}$ & $\begin{array}{c}\text { Faculty: Ph.D. } \\
\text { Awarded/ year } \\
\text { ratio }\end{array}$ \\
\hline $\begin{array}{l}\text { North } \\
\text { zone }\end{array}$ & $\begin{array}{l}\text { University } \\
\text { of } \\
\text { Rajasthan } \\
\text { Panjab } \\
\text { University }\end{array}$ & $1: 1.56$ & $1: 0.63$ \\
\hline $\begin{array}{l}\text { East } \\
\text { zone }\end{array}$ & $\begin{array}{l}\text { University } \\
\text { of Calcutta } \\
\text { Patna } \\
\text { University }\end{array}$ & $1: 1.02$ & $1: 0.36$ \\
\hline $\begin{array}{l}\text { North- } \\
\text { east } \\
\text { zone }\end{array}$ & $\begin{array}{l}\text { Gauhati } \\
\text { University } \\
\text { Sikkim- } \\
\text { Manipal } \\
\text { University }\end{array}$ & $1: 0.14$ & $1: 0.29$ \\
\hline $\begin{array}{l}\text { South } \\
\text { zone }\end{array}$ & $\begin{array}{l}\text { University } \\
\text { of Madras } \\
\text { University } \\
\text { of Mysore }\end{array}$ & $1: 1.96$ & $1: 0.26$ \\
\hline $\begin{array}{l}\text { West } \\
\text { zone }\end{array}$ & $\begin{array}{l}\text { University } \\
\text { of Mumbai } \\
\text { University } \\
\text { of Pune }\end{array}$ & $1: 0.93$ & $1: 1.25$ \\
\hline
\end{tabular}

Source: Annual reports of the universities;

University official website; "Google search;

Validated data received from the universities; NA- Not available. allowed to supervise $\mathrm{PhD}$ students. One of the reasons for a higher number of students enrolling for $\mathrm{PhD}$ program and subsequent awards of $\mathrm{PhD}$ degree in University of Madras was it received maximum research funding of 41.46 crores rupees for 221 ongoing projects. The ratio of number of faculty to research publications ranged from 1:0.05 to 1:1.9. University of Madras, Panjab, Rajasthan and Calcutta have more than 1:1 ratio. In the Universities of Mysore, Pune and Gauhati, the ratios were respectively 1:0.9, 1:0.6 and 1:0.6. However, the Patna University and University of Mumbai showed the least ratios respectively $1: 0.1$ and 1:0.2 (Table 2). The ratio for the southern and northern zone universities was higher when compared with other regions of the country.

In the year 2005, a total of $2857 \mathrm{PhDs}$ was awarded from different universities in the

Table 3. Comparative research funding in the state universities selected from different zones

\begin{tabular}{|c|c|c|c|c|c|}
\hline Region & State Universities & $\begin{array}{l}\text { Ongoing } \\
\text { research } \\
\text { projects }\end{array}$ & $\begin{array}{l}\text { Funding for } \\
\text { research } \\
\text { projects }\end{array}$ & $\begin{array}{c}\text { Department/sections recognized } \\
\text { under various national programmes } \\
\text { (SAP/CAS/DRS/ DSA/COSIST/FIST) }\end{array}$ & $\begin{array}{l}\text { No: of faculty members } \\
\text { as members of } \\
\text { professional bodies }\end{array}$ \\
\hline $\begin{array}{l}\text { North } \\
\text { zone }\end{array}$ & $\begin{array}{l}\text { University of } \\
\text { Rajasthan } \\
\text { Panjab University }\end{array}$ & $\begin{array}{l}33 \\
79\end{array}$ & $\begin{array}{l}12 \text { crores } \\
5.33 \text { crores }\end{array}$ & 5 & $\begin{array}{l}5 \\
7\end{array}$ \\
\hline $\begin{array}{l}\text { East } \\
\text { zone }\end{array}$ & $\begin{array}{l}\text { University of Calcutta } \\
\text { Patna University }\end{array}$ & $\begin{array}{c}175 \\
14\end{array}$ & $\begin{array}{l}14.3 \text { crores } \\
0.93 \text { crores }\end{array}$ & $\begin{array}{c}20 \\
1\end{array}$ & $\begin{array}{l}>5 \\
-\end{array}$ \\
\hline $\begin{array}{l}\text { North- } \\
\text { east } \\
\text { zone }\end{array}$ & $\begin{array}{l}\text { Gauhati University } \\
\text { Sikkim- Manipal } \\
\text { University }\end{array}$ & $\begin{array}{l}56 \\
\text { NA }\end{array}$ & $\begin{array}{l}5.06 \text { crores } \\
\text { NA }\end{array}$ & $\begin{array}{l}4 \\
-\end{array}$ & $\begin{array}{c}>5 \\
-\end{array}$ \\
\hline $\begin{array}{l}\text { South } \\
\text { zone }\end{array}$ & $\begin{array}{l}\text { University of Madras } \\
\text { University of Mysore }\end{array}$ & $\begin{array}{c}221 \\
85\end{array}$ & $\begin{array}{l}41.46 \text { crores } \\
4.62 \text { crores }\end{array}$ & $\begin{array}{c}20 \\
9\end{array}$ & $\begin{array}{c}>5 \\
2\end{array}$ \\
\hline $\begin{array}{l}\text { West } \\
\text { zone }\end{array}$ & $\begin{array}{l}\text { University of Mumbai } \\
\text { University of Pune }\end{array}$ & $\begin{array}{l}135 \\
70\end{array}$ & $\begin{array}{l}5.30 \text { crores } \\
16.02 \text { crores }\end{array}$ & $\begin{array}{l}12 \\
11\end{array}$ & $\begin{array}{l}80 \\
>5\end{array}$ \\
\hline
\end{tabular}

Source: Annual reports of the universities; University official website; Google search; validated data received from the universities; NA- Not available

Growth of highest degrees awarded (Ph.D.)

From the results it can be seen that the ratio of the number of faculty to the number of $\mathrm{PhD}$ degree awarded every year varied from 1:0.2 to 1:1.3. Only University of Madras has a ratio that is more than $1: 1$. The number of PhDs awarded is dependent on number of students enrolling for $\mathrm{PhD}$ programme, research fellowships, research projects, grants received, and number of faculty country (Vidyanidhi, 2006). The number and quality of $\mathrm{PhD}$ degrees awarded from university to another varied greatly depending on the availability of funds, ongoing research schemes, quality of faculty and facilities for the research students. The mandatory requirements for awarding degree were not uniform among the universities. But for instance, in Chinese universities it is mandatory to have two publications in journals with a high
Sci. Technol.Edu.

CIndian Society for Education and Environment (iSee)
"Comparison among Indian universities" http://www.indjst.org
Shetty et al. Indian J.Sci.Technol. 
impact factor for submission of a PhD thesis. This mandatory requirement is also followed in some of the state universities but majority of them are not following this as it is not essential for the award of the degree. with 221 ongoing projects (70 projects are departmental projects) with a funding of 41.46 crore rupees. However, in the other selected southern zone university, University of Mysore has 85 ongoing research projects with a

Table 4. Centers of excellence and the initial grant received and other comparative profiles of the state universities selected from different zones

\begin{tabular}{|c|c|c|c|c|}
\hline State Universities & Center for excellence & $\begin{array}{l}\text { UGC initial } \\
\text { grant }\end{array}$ & $\begin{array}{c}\text { No: of faculty } \\
\text { members won the } \\
\text { national \& } \\
\text { international awards }\end{array}$ & $\begin{array}{c}\text { No: of faculty } \\
\text { members visited } \\
\text { abroad for academic } \\
\text { activities / year }\end{array}$ \\
\hline $\begin{array}{l}\text { University of Rajasthan } \\
\text { Panjab University }\end{array}$ & Bio-medical sciences & 5 crores & $\begin{array}{l}12 \\
12\end{array}$ & $\begin{array}{l}<5 \\
<5\end{array}$ \\
\hline University of Calcutta & 42 chairs of excellence & NA & 42 & $>5$ \\
\hline Patna University & - & - & $<5$ & $<5$ \\
\hline Gauhati University & - & - & 48 & $<5$ \\
\hline Sikkim-Manipal University & NA & NA & - & NA \\
\hline University of Madras & $\begin{array}{l}2 \text { B Botany (Herbal Sciences) \& } \\
\text { Mathematics\} }\end{array}$ & $\begin{array}{l}30.96 \\
\text { crores }\end{array}$ & $>5$ & $>5$ \\
\hline University of Mysore & $\begin{array}{l}4 \text { (Botany, library and information } \\
\text { science, geology and zoology) }\end{array}$ & NA & 11 & $<5$ \\
\hline University of Mumbai & Department of chemical technology & NA & 18 & 20 \\
\hline University of Pune & Bio-informatics and biotechnology & 30 crores & 30 & 10 \\
\hline
\end{tabular}

Source: Annual reports of the universities; University official website; Google search; NAAC reports; Validated data received from the universities

Database on dissertation (theses) of Indian universities

An initiative to create a database on dissertation was undertaken in the year 2000 by the Department of Library and Information Science, University of Mysore. This project was sponsored by National Information system for Science and Technology (NISSAT), Department of Scientific and Industrial Research (DSIR), The Ford Foundation and The Microsoft, India. It has successfully created the database for Indian Theses "Vidyanidhi". This project was aimed to evolve as an information infrastructure and an enabling framework for strengthening research capacities in Indian Universities.

\section{Research funding}

University of Madras has the highest research funding with 41.46 crores among the selected universities. All the PhD students get a fellowship from their respective departments to complete their $\mathrm{PhD}$. Pune University received the second highest research funding with 16.02 crore rupees among the selected state universities (Table 3 ). The Pune University had spent $68 \%$ of its resources from its budget on research activities. The ISO certification of the finance wing has helped Pune University getting more funds for projects from industries as well as funding agencies. NAAC reaccreditation, quality education, quality faculty, good research output and a good organizational management of University of Madras helped receiving more funds when compared to other selected universities in the country.

The results from this study showed that there was both regional and intraregional disparity in fund allocation among the selected universities. In terms of number of projects and funding, University of Madras gone ahead funding of Rs. 4.62 crore rupees. University of Calcutta has 175 ongoing projects with a funding of 14.3 crore rupees. The other eastern zone university namely Patna University, which has only 14 ongoing research projects with a funding of. 0.93 crore rupees. Among the selected universities, Patna in the eastern zone, University of Mysore in the southern zone and the Gauhati University in north-east zone received less funds when compared to other universities selected for the study (Table 3).

Nearly 432 departments have been identified to be availing Special Assistance Programme (SAP) during the Tenth Plan period till 2005 in the country (Nigavekar, 2005). This disparity in the number of projects and funding within the region and also among the different zones is an unhealthy sign that needs to be resolved. There is not much zone wise difference in terms of special assistance given by UGC to state university departments among the selected universities. Twenty departments in Calcutta, Panjab and Madras University were recognized to receive funding under SAP/COSIST/FIST schemes. However, in the eastern zone Patna University, only one department was recognized to receive such funding (Table 3 ).

In 1966, the Education Commission (1964-66) (chaired by $D S$ Kothari) had recommended that we should allocate 6 percent of national income to education. But the goal has remained unfulfilled till now. In the developed countries (U.S., U.K. and Australia) the major sources of funding is the interest of investments, differentiated fee structure for foreign students, commercialized research and development via licensing of intellectual property, research collaborations with industry, gifts from philanthropic individuals as well as
Sci. Technol.Edu.

CIndian Society for Education and Environment (iSee)
"Comparison among Indian universities" http://www.indjst.org
Shetty et al. Indian J.Sci.Technol. 


\begin{tabular}{|c|c|c|c|c|}
\hline \multirow{3}{*}{$\begin{array}{l}\text { large and established } \\
\text { alumni networks, } \\
\text { continuing and distance } \\
\text { education programmes, } \\
\text { other degree and non- } \\
\text { degree night and weekend }\end{array}$} & \multicolumn{4}{|c|}{$\begin{array}{l}\text { Table 5. International academic links, industry links and the } \\
\text { research institution links established with the state universities }\end{array}$} \\
\hline & State Universities & $\begin{array}{l}\text { International } \\
\text { academic } \\
\text { links }\end{array}$ & $\begin{array}{c}\text { Industry } \\
\text { links }\end{array}$ & $\begin{array}{l}\text { Research } \\
\text { institution } \\
\text { links }\end{array}$ \\
\hline & Unive & 14 & $<5$ & 11 \\
\hline courses, such as & $\begin{array}{l}\text { Rajasthan } \\
\text { Panjab University }\end{array}$ & 5 & 0 & 0 \\
\hline $\begin{array}{l}\text { xecutive } \\
\text { BA }\end{array}$ & $\begin{array}{l}\text { University of } \\
\text { Calcutta }\end{array}$ & 25 & 15 & $>5$ \\
\hline ofessional & Patna University & $<5$ & $<5$ & $<5$ \\
\hline urses etc. Besides, U.S., & Gauhati University & $<5$ & $<5$ & $<5$ \\
\hline K. and Australian & $\begin{array}{l}\text { Sikkim- Manipal } \\
\text { University }\end{array}$ & 4 & $>5$ & $>5$ \\
\hline $\begin{array}{l}\text { fty fees for foreign } \\
\text { tionals when compared } \\
\text { local students. Funds }\end{array}$ & $\begin{array}{l}\text { University of Madras } \\
\text { University of Mysore } \\
\text { University of } \\
\text { Mumbai }\end{array}$ & $\begin{array}{c}2 \\
6 \\
27\end{array}$ & $\begin{array}{c}50 \\
5 \\
30\end{array}$ & $\begin{array}{l}52 \\
49 \\
90\end{array}$ \\
\hline ted & University of Pune & $>5$ & $>5$ & 119 \\
\hline
\end{tabular}
consultancies and commercial spin-offs, funding from international

Source: Annual reports of the universities; University official website; NAAC peer review reports
Vol. 3 No. 3 (Mar 2010)

ISSN: 0974- 6846 agencies such as the World Bank or the Asian Development Bank for specific projects, such as setting up campuses in developing countries or development related research projects. It is essential that Indian Universities take some lessons from these international universities to improve and manage funds and utilize them for scientific research.

\section{Centers of excellence in the universities}

Keeping in view of the excellent achievements of the university in particular fields, "Centres for Excellence" have been sanctioned to different universities by the UGC to provide meritorious education in line with the new developments and challenges (Table 4). The University of Calcutta has 42 chairs of excellences in recognition to their pioneering works in their respective fields of interests. The university also initiated a study in Nanoscience. This has not only helped it to be among top universities in India but also helped to increase the output in terms of publications and citations. The University of Mumbai has the Department of Chemical Technology. It has achieved excellence in association with a number of chemical companies in Mumbai. University of Pune has bio-informatics and biotechnology being taught as subjects with an initial grant of Rs. 30 crores from UGC (UPAR, 2005). Panjab University has introduced Biomedical sciences with an initial grant of Rs. 5 crores from UGC (Table 4). Hence "Centres for Excellence" in these universities have proven to be a motivation for improving higher education and also their output. The UGC has also provided these universities with additional funds and thereby improved the departments and the

Sci. Technol.Edu.

CIndian Society for Education and Environment (iSee)
Table 6.Number of patents registered by the different universities

\begin{tabular}{|c|l|c|}
\hline Region & State Universities & Patents \\
\hline North & University of Rajasthan & NA \\
zone & Panjab University & 31 \\
\hline \multirow{2}{*}{ East zone } & University of Calcutta & 10 \\
\cline { 2 - 3 } & Patna University & - \\
\hline North east & Gauhati University & 2 \\
zone & Sikkim- Manipal University & NA \\
\hline South & University of Madras & 11 \\
zone & University of Mysore & 3 \\
\hline \multirow{2}{*}{ West zone } & University of Mumbai & NA \\
& University of Pune & NA \\
\hline
\end{tabular}

"Comparison among Indian universities" http://www.indjst.org infrastructure.

International academic links

India currently has Science and Technology cooperation agreements with 57 countries including the G8 countries such as France, Germany, Italy, Japan, UK and the USA. Amongst the emerging economies China and Brazil (Seethapathy \& Johnston, 2004) are included. The Human Frontier Science Program Organisation (HFSPO) included India as a member country after December $4^{\text {th }}, 2006$. Scientists from India will now be able to participate fully in the research grant award cycles as Principal Investigators. However, State universities have 4-27 international academic linkages. There is lot of scope in promoting interactions between governments, academia, institutions and industries through which India and partner countries can be benefited. The interconnection that research, consultancy and extension have achieved is vital for both academic progress and self-development.

Industry - academia linkages

Industry's interests are mainly applied in nature whereas universities or academic institutions channel their efforts and resources in fundamental and unidirectional research (Kathuria, 2004). Much of the current debate on university-industry links focused on a narrow range of activities such as spin-offs and start-ups from universities and higher education institutes, and the licensing of intellectual property. The results from this study showed that University of Mumbai, Calcutta, Pune, Madras and Mysore have established 5 to 30 links with industries. University of Rajasthan, Gauhati and Patna have less links with industry compared to other selected universities (Table 5). Academia-Industry Interface is a less researched area specifically in management education in India. Though regarded as a critical challenge to management education in India (Aggarwal et al., 2004), very little has been suggested on the right path and strategy of cashing on this partnership and aligning it for the benefit of both business and the academics.

\section{Research institution links}

There is a paradigm shift underway in how science is done around the world. Inter- 
Table 7. Criterion-wise scores of selected state universities

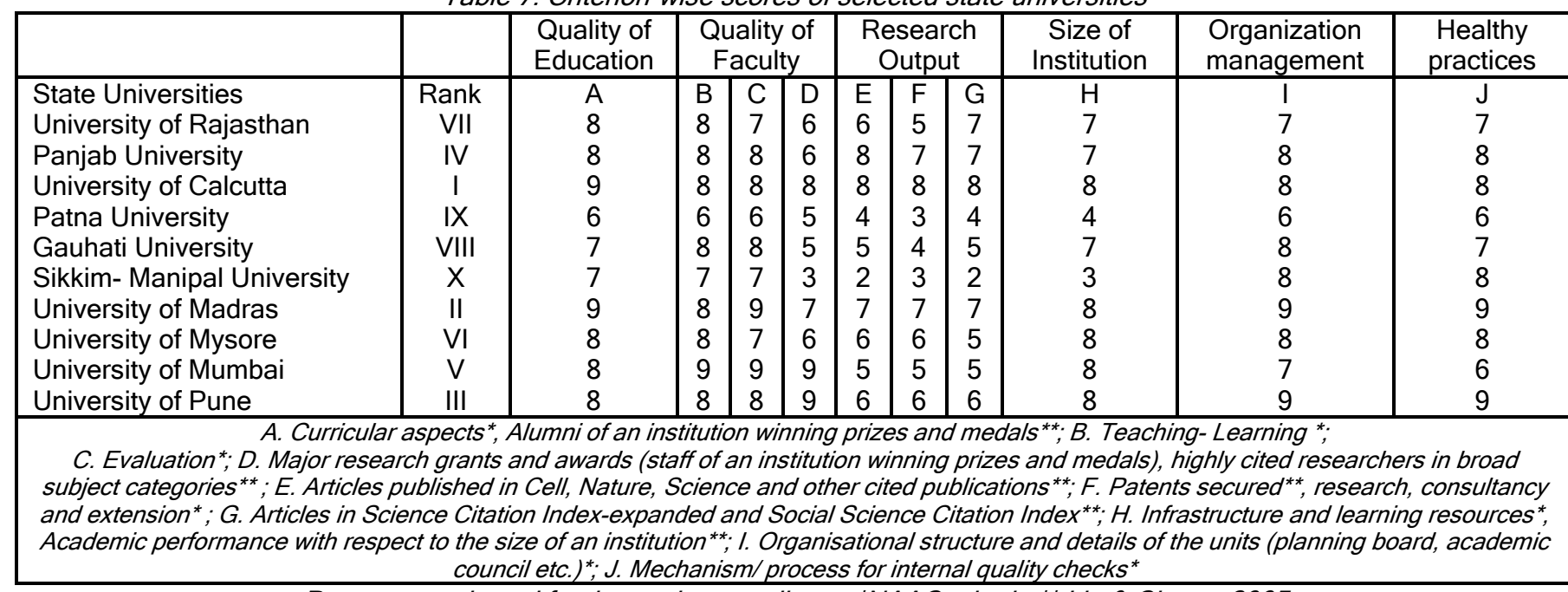

Parameter selected for the study according to *NAAC criteria ** Liu \& Cheng, 2005

disciplinarity and multi-disciplinarity are becoming the norm in the approach to research problem-solving. The activities and aspirations of researchers are shifting to areas like biotechnology and nanoscience. The University of Pune, Mumbai,

Mysore and Madras have established 119, 90, 49, and 52 research institution links respectively. Pune and Mumbai universities have established more research institution links when compared with other zone universities (Table 5). This has not only helped these universities but has also helped the students and faculty to perform much better.

\section{Patents}

Among the selected universities, Calcutta University has a total of 10 patents in the last 10 years. Rest of the universities have two to three patents or have just filed for patents. The patent facilitation cell has been established to promote national and international patents of indigenous innovations. In biotechnology, 112 patents have been filed for out of which 7 international patents and 7 national patents have been granted as on December 2005. Although patent filings in India have gone up four-fold in the last five years, they are still relatively low when compared to other Asian countries like South Korea, China and Taiwan.

\section{Technometrics}

The analysis of patents granted, using the questionnaire survey and university data provides insight into the intensity and significance of inventive activity in the state universities. Owing to the constraints both of time and of the antiquated classification system in the collected data, our technometric analysis has been rather cursory. Panjab University is particularly strong in Biomedical sciences and pharmaceuticals (complementing research and technology strengths noted with centre of excellence). Panjab University has registered thirty one patents by the university Institute of Pharmaceutical Sciences and the Department of Chemistry on the basis of research conducted in the Sci. Technol.Edu. CIndian Society for Education and Environment (iSee)
University and collaborative research with scientists in the USA. State universities have produced considerable intellectual property in the

pharmaceutical sector and in biotechnology, but this is not cited as often as the other national institutes' and private companies' average for other patents in these fields, suggesting that their technological importance, in the aggregate, is lower than the world average (Table 6).

\section{Postdoctoral fellowships}

Among the state universities selected, about 40, 27 and 1 post doctoral fellows were working in Calcutta, Rajasthan and Mysore universities respectively. In rest of the universities, no post doctoral students were working. Other selected universities also needed to encourage post doctoral fellows to continue research with scientists in their universities to increase the research output. Department of Biotechnology (DBT) is providing around 50 post-doctoral fellowships per year to encourage research in biotechnology at different research institutes and universities in India. Similarly, UGC is also providing 100 post-doctoral fellowships per year to encourage research students belonging disadvantaged community students.

\section{Criterion-wise scores of select state universities}

The criterion-wise scores and the rankings with the available information of ten selected state universities in different zones are presented in the following table in line with the NAAC rating (Table 7). Calcutta University topped the list followed by Madras University. At present there are nearly 48 million educated registered unemployed people in the country. Of these about 8.1 and 3.9 percent have graduate and post graduate degrees respectively (ISR, 2005). In all the selected universities, students' alumni associations and career guidance centre were established. These centers should make more coordinated effort to assist students at large. We need better monitoring system of higher education institutions. Our courses must be updated with emphasis on skill development and research. In modern days and
"Comparison among Indian universities" http://www.indjst.org
Shetty et al. Indian J.Sci.Technol. 
age of rapid change, frequent technology upgrading and competition were important for universities to stay up-todate with the latest curriculum and incorporate best practices to stay afloat.

Concluding comments

Indian universities need to be dynamic and adoptive to the changing needs and priorities of the society and should provide an arena of freedom to young innovative minds. It is disturbing that the number of students opting for undergraduate courses in basic sciences is declining. The public-private partnerships will have tremendous influence on the development of technologies and how these are managed. There is a need for high level of funding for research, including contractual research. A critical review of activities of higher educational institutions as well as their budgets needs to be conducted to phase out obsolete activities and create necessary space for new activities. The shifting from traditional incremental budgeting to a performance based one is now necessary to arrest the erosion in quality and the resource crunch. The institutes are under-financed and under-staffed. Effort can be made to harness the full potential of trained workforce. Along with the necessary and inevitable quantitative expansion of higher education, it is equally important to improve the quality of higher education. Institutions of higher education would find it difficult to meet the challenges of globalization of higher education if one fails in this front. Emphasis on quality parameters becomes all the more necessary in the light of mushrooming of private institutions with the opening up of the Indian economy.

Setting up of NAAC has sent the right and positive signals for generating and promoting awareness of the urgent need of quality up-gradation of Colleges and Universities. The urgent need is to identify effective ways and strategies to expedite the completion of assessment, accreditation and re-accreditation by NAAC within a stipulated timeframe. Some recommendations made in the Report on University Science Education made by the Indian Academy of Sciences in 1994 are very relevant even today. We would like to renew the importance of the following again. One should encourage the notion of adjunct faculty, which would enable outstanding scientists outside the university system to participate in teaching in universities. One step in this direction might be to create a fund to support teaching and research ventures undertaken jointly by faculty in universities and scientists in national laboratories. Industry too should come forward with scholarships for students and support to laboratories.

\section{Acknowledgements}

This article is based on the project funded by Department of Science and Technology, Government of India.

\section{References}

1. Aggarwal A, Rizvi IA and Popli S (2004) Global branding of business schools: an Indian perspective. Welingkars Res. J. 2 (4), 2-31.
Vol. 3 No. 3 (Mar 2010)

ISSN: 0974- 6846
2. CABE (2005). Central Advisory Board of Education Report of the CABE committee on Financing of Higher and Technical Education. http://www.niepa.org. Accessed 7 March 2006.

3. Gauhati University (2005). Annual reports (2003-2005).

4. http://www.ugc.ac.in Accessed 8 Jun.2007.

5. India Science Report (2005). Science Education, Human Resources and Public Attitude towards Science and Technology. Published by National Council of Applied Economic Research, New Delhi.

6. Kathuria V (2004) For stronger industry-lab linkages. The Hindu, March 29.

7. Liu NC and Cheng Y (2005) Academic ranking of world universities- methodologies and problems http://ed.sjtu.edu.cn/ranking.htm. Accessed 2 Feb 2006.

8. Mishra S (N.D.) Funding by University Grants Commission, Education, Centre for Civil Society, 341-355. Retrieved on 16 December 2006 from http://www.ccsindia.org/ccsindia/pdf/wp0071.pdf

9. Miyairi N (2006) World class research from India: Thomson scientific citation analysis, Essential Science Indicators.

10. NAAC (2005) National Assessment and Accreditation Council. A profile. http://www.naac-india.com Accessed 1 Jan.2007.

11. Nigavekar A (2005) Ensuring quality higher education for all. Country Report: India. www.unesco.or.kr/kor/ activity2005/ed/data_wche/CountryReportIndia.doc.

Accessed 1 June 2006.

12. NSTMIS (2005) Research and Development Statistics. http://www.nstmis-dst.org. Accessed 8 June 2006.

13. Panjab University (2005) Annual reports (2002-2005).

14. Patna University (2005). Annual reports (2003-2005).

15. Rahm $E$ and Thor $A$ (2005) Citation analysis of database publications. SIGMOD Record. 34 (4) 48-53.

16. Seethapathy R and Johnston D (2004) S\&T ReportInstitutional linkages: Academic /Government /Private Partnerships: In the Canadian and Indian Science and Technology Sector (Canada-India S\&T Mapping Study). pp: 25.

17. UGC (2005) University Grants Commission. Annual Reports, 1990-2005.

18. UGC (2006) University Grants Commission http://www.ugc.ac.in. Accessed 8 June 2006.

19. University of Calcutta (2005) Annual reports (2000-2003). 20. University of Madras (2006) Annual reports (2003-2006).

21. University of Mumbai (2005) Annual reports (2002-2004).

22. University of Mysore (2005) Annual reports (2003-2005).

23. University of Pune (2005) Annual reports (2002-2005).

24. University of Rajasthan (2003) Annual reports (20022003).

25. Vidyanidhi (2006) http://www.vidyanidhi.org. Accessed 7 March 2006.

26. Wikipedia (2006) Education in India. Wikimedia Foundation, Inc. Retrieved on 16 Dec. 2006 from http://en.wikipedia.org/wiki/Education_in_India

27. WOS (2005) Web of Science - Thomson Scientific Report. http://www.scientific.thomson.com. Accessed 5 May 2006.
Sci. Technol.Edu.

CIndian Society for Education and Environment (iSee)
"Comparison among Indian universities" http://www.indjst.org
Shetty et al. Indian J.Sci.Technol. 